\title{
Capitalized Human Resources Cost and Its Influence on Corporate Productivity: A Study of Selected Companies in Nigeria
}

\author{
Bassey Eyo Bassey \\ Department of Accounting \\ Faculty of Management Sciences \\ University of Calabar \\ P.M.B.1115., Calabar \\ Tel: $+23-480-3798-3154$ \\ Arzizeh Tiesieh Tapang (Corresponding author) \\ Faculty of Management Sciences \\ University Of Calabar \\ P.M.B.1115., Calabar \\ Tel: +23-480-3273-7920,+23-480-9551-4973_E-mail: arzizeh01@yahoo.com
}

Received: February 1, 2012

Accepted: March 5, 2012 Published: April 15, 2012

doi:10.5430/ijfr.v3n2p48

URL: http://dx.doi.org/10.5430/ijfr.v3n2p48

\begin{abstract}
This study aimed at examining the influence of human resources cost on corporate productivity. Human resources have been identified as one of the main sources of competitive advantage by many organizations in today's economy. In other to investigate the above issue, the researcher gathered data from ten (10) companies listed in the Nigerian Stock Exchange with the aid of a questionnaire using an ex-post facto design. The study revealed that acquisition and development costs are important determinants of human resources cost and does significantly influence corporate productivity. Conclusively, human resources cost approach to corporate performance measurement which have gained substantial attention and use in recent years provides further opportunities for utilization of human resource accounting measures. The study recommended that companies should use career management programs to assist their employees in career planning.
\end{abstract}

Keywords: Human Resources Cost, Human Resource Costing, Human Capital, Human Resources Cost Report, Acquisition Cost, Development Cost

\section{Introduction}

The advent of Information and Communication Technology (ICT) has globalized the earth. This has altered both the socio political and business settings. In either case human effort has taken the centre stage. This is because every business requires physical assets as well as human resources for its success. Without human resources and efforts physical assets like land, buildings, plants, machines, and even the electronic gadgets become unproductive. All the activities plans, strategies of a concern are initiated, executed, implemented, managed and controlled by the manpower that makes the concern. Profitability, productivity, solvency and efficiency of any organization are largely depended upon the human resources. Knowledge or skilled based companies are much richer than the physical or financial bearing companies. Since intellectual, experience, know-how, attitude, behaviour and value system of employees with a different way can improve the efficiency of production or services and create more wealth to an organization. Human resources are the creative and innovative force which strives to secure maximum results (Brummet, 1970). The concept of human resource accounting is in the early stage of development in developing countries like Nigeria, Ghana, Cameroon and etc. Similarly, the total worth of the organization depends mainly on the skills of its employees and the services they render. Hence, the success of these organizations is contingent on the quality of their human resource. In knowledge driven economies therefore, it is imperative that the human elements be recognized as an integral part of the 
total worth of an organization. However, in order to estimate and project the worth of the human capital, it is necessary that some method of quantifying the worth of the knowledge, motivation, skills, and contribution of the human elements be ascertained. Human Resource Accounting (HRA) denotes just this process of quantification/measurement of the Human Resource (Prasad \& Kumar, 2006).

The concept of human resource accounting was first developed by Sir William Petty in the year 1691. "Research into true human resource accounting began in the 1960 by Reris Likert". According to American Accounting Association (1974), human resource accounting is the process of identifying and measuring data about human resources and communicating this information to interested parties. Thus human resource accounting would measure all the data relating to people in an organization, which will be helpful in making relevant decisions regarding internal and external matters. Like other physical assets human assets also have ability to create income. A person is appointed in a business concern and given services during bonded period, separation point or life normally up to supper annuation age. Therefore, it is necessary to value human forces just as other assets (Cascio, 1998). A number of models have been developed to value human assets. A concern incurs two types of expenditure on human assets.

i. Capital expenditure: which embodies acquisition, development, retention, updates or up gradation cost.

ii. Revenue expenditure: including wages, salaries, bonus, commission, perquisites, allowances and short term motivation and efficiency maintenance cost.

Value of human resource can be calculated either on the basis of cost of production approach or the capitalized earning approach. Capital expenditure are written off over the expected life of employees while revenue expenditure are written off or charged in company's profit \& loss account of current year (Cascio,1998).

The following research hypotheses were posted to guide and direct the paper

1. $\mathrm{H}_{\mathbf{0}}$ : Human resources acquisition cost does not have a significant influence on corporate productivity.

2. $\mathrm{H}_{\mathbf{0}}$ : Human resources development cost does not have a significant influence on corporate productivity.

\section{Literature Review and Theoretical Framework}

\subsection{Theoretical Framework}

The belief that individual employee performance has implications for firm-level outcomes has been prevalent among academics and practitioners for many years. Interest in this area has recently intensified; however, as scholars have begun to argue that collectively, a firm's employees can also provide a unique source of competitive advantage that is difficult for its competitors to replicate. For example, Wright and McMahan (1992), drawing on Barneys (1991) resource-based theory of the firm, contended that human resources can provide a source of sustained competitive advantage when four basic requirements are met. First, they must add value to the firm's production processes; levels of individual performance must matter. Second, the skills the firm seeks must be rare. Since human performance is normally distributed, Wright and McMahan (1992) noted, all human resources meet both of these criteria. The third criterion is that the combined human capital investments a firm's employees represent cannot be easily imitated. Although human resources are not subject to the same degree of limitability as equipment or facilities, investments in firm-specific human capital can further decrease the probability of such imitation by qualitatively differentiating a firm's employees from those of its competitors. Finally, a firm's human resources must not be subject to replacement by technological advances or other substitutes if they are to provide a source of sustainable competitive advantage. Although labor-saving technologies may limit the returns for some forms of investment in human capital, the continuing shift toward a service economy and the already high levels of automation in many industries make such forms of substitution increasingly less probable.

Wright and McMahan's (1992) work points to the importance of human resources in the creation of firm-specific competitive advantage. At issue, then, is whether, or how, firms can capitalize on this potential source of profitability. Bailey (1993) contended that human resources are frequently "underutilized" because employees often perform below their maximum potential and that organizational efforts to elicit discretionary effort from employees are likely to provide returns in excess of any relevant costs. He argued that Human Resource Management (HRM) practices can affect such discretionary effort through their influence over employee skills and motivation and through organizational structures that provide employees with the ability to control how their roles are performed.

Human resource management practices influence employee's skills through the acquisition and development of a firm's human capital. Recruiting procedures that provide a large pool of qualified applicants, paired with a reliable and valid selection regimen, will have a substantial influence over the quality and type skills new employees possess. Providing 
formal and informal training experiences, such as basic skills training, on-the-job experience, coaching, mentoring, and management development, can further influence employees' development.

The effectiveness of even highly skilled employees will be limited if they are not motivated to perform. However, and HRM practices can affect employee motivation by encouraging them to work both harder and smarter. Examples of firm efforts to direct and motivate employee behaviour include the use performance appraisals that assess individual or work group performance, linking these appraisals tightly with incentive compensation systems, the use of internal promotion systems that focus on employee merit, and other forms of incentives intended to align the interests of employees with those of shareholders (e.g. profit-and gain-sharing plans).

Finally, Bailey (1993) noted that the contribution of even a highly skilled and motivated workforce will be limited if jobs are structured, or programmed, in such a way that employees, who presumably know their work better than anyone else, do not have the opportunity to use their skills and abilities to design new and better ways of performing their roles. Thus, HRM practices can also influence firm performance through provision of organizational structures that encourage participation among employees and allow them to improve how their jobs are performed. Cross-functional teams, job rotation, and quality circles are all examples of such structures.

Thus, the theoretical literature clearly suggests that the behaviour of employees within firms has important implications for organizational performance and that human resource management practices can affect individual employee performance through their influence over employees' skills and motivation and through organizational structures that allow employees to improve how their jobs are performed. If this is so, a firm's HRM practices should be related to at least two dimensions of its performance. First, if superior HRM practices increase employees' discretionary effort, we would expect their use to directly affect intermediate outcomes, such as productivity over which employees have direct control. Second, if the returns from investments in superior HRM practices exceed their true costs, then lower employee turnover and greater productivity should in turn enhance corporate financial performance. Therefore, in anticipation of an estimation model that focuses on these dependent variables, our review of the empirical literature concentrates on prior work examining the influence of human resources cost (HRC) on corporate productivity.

Theoretical perspectives based in sociology, economics, management, and psychology focus on different aspects of the domain of human resource management in context (Wright \& McMahan, 1992). We begin by offering brief summaries of the perspectives that have guided most of the empirical studies reviewed in this study and that we feel are most likely to drive future research.

\subsubsection{Transaction Cost Theory}

This theory assumes that business enterprises choose governance structures that economize transaction costs association with establishing, monitoring, evaluating, and enforcing agreed upon exchanges (Williamson, 1979 and 1981). Predictions about the nature of the governance structure an enterprise will use incorporate two behavioural assumptions: bounded rationality and opportunism (i.e. the seeking of self-interest with guile). These assumptions mean that the central problem to be solved by organizations is how to design governance structures that take advantage of bonded rationality while safeguarding against opportunism. To solve this problem, implicit and explicit contracts are established, monitored, enforced, and revised. The theory has direct implications for understanding how HRM practices are used to achieve a governance structure for managing the myriad implicit and explicit contracts between employers and employees (Wright \& McMahan, 1992). For example, organizations that require firm specific knowledge and skills are predicted to create internal labour markets that bind self-interested and bounded rational employees to the organization, while organizations that do not require these skills can gain efficiencies by competing for self-interested and bounded rational talent in an external labour market (Williamson, 1981). Contextual factors, in turn, partly determine whether the types and amounts of skills and knowledge a firm needs are likely to be available in the external labour market, the costs of acquiring them from the external market, the organization's capability for developing them internally, and the costs of doing so.

\subsubsection{Human Capital Theory}

In the economics literature, human capital refers to the productive capabilities of people (Becker, 1964). Skills, experience, and knowledge have economic value to organizations because they enable it to be productive and adaptable; thus people constitute the organization's human capital. Like other assets, human capital has value in the market place, but unlike other assets, the potential value of human capital can be fully realized only with the co-operation of the person. Therefore, all costs related to eliciting productive behaviours from employees including those related to motivating, monitoring, and retaining them-constitute human capital investments made in anticipation of future returns (Flamholtz \& Lacey, 1981). Organizations can use human resource management in a variety of ways to increase their 
human capital (Cascio, 1991; Flamholtz \& Lacey, 1981). For example, they can "buy" human capital in the market (e.g. by offering extensive training and development opportunities). Investments of either type have associated costs, which are justifiable only to the extent the organization is able to productively utilize the accumulated capital (Tsang et al., 1991). In human capital theory, contextual factors such as market conditions, unions, business strategies, and technology are important because they can affect the value of the organization's human capital and the value of the anticipated returns, such as productivity gains (e.g. Boudreau \& Berger, 1985; Russell et al., 1993).

\subsubsection{General System Theory}

This theory is propounded by Von-Bertalanffy in 1950. In general, system theory unit of analysis is understood as a complex of interdependent parts. An open versus closed system is dependent on the environment for inputs which are transformed throughout to produce outputs that are exchanged in the environment. Open systems models seldom address organizations or large units within organization. According to Katz and Kahn's (1978), the social psychology of organizations is an exception in that it treats human resource management has been developed further by Wright and Snell (1991), who used it to described a competent management model of organizations. Skills and abilities are treated as inputs from the environment; employee behaviours are treated as throughout; and employee satisfaction and performance are treated as outputs. In this model, the HRM subsystem functions to acquire, utilize, retain, and displace competencies. Similarly, Snell's (1992), description of human resource management as a control system is based in open systems theory. In a more narrow discussion Kozlowski and Salas (1994), presented a multilevel organizational systems approach for understanding training implementation and transfer.

\subsection{Reporting Human Resources Cost}

Dominating views about existent reports on human resources cost in the accounting field of Nigeria are on the consideration of characteristics of intangible assets of human assets, the item of "human assets" could be inserted between "intangible assets" and "deferred assets" in the balance sheet so as to reflect the net amount of human resources cost after being deduct the amortization. The human assets amortization expenses could be added in "management expenses" of enterprise profit and loss statement (Wan-xiang, 2001).

Report of human assets could be divided into internal report and external report. The internal report includes adjusted balance sheet, profit statement and cash flow statement. In balance sheet, initial assets value, amortization amount and net value will be displayed respectively on one hand; situation of human resources will be disclosed in annotations from angles of static and dynamic states on the other hand. The item of "Human resources" could be added in profit statement in order to reflect enterprise incurred expenses which shall not be capitalized and amortization of human assets for the purpose of using human resources. Meanwhile, relevant adjustment should be adapted to contents reflected by "Management expenses" and other accounts. The reflection of cash flow incurred in investment activities of cash flow statement. In addition, reports of human resources investment, flow and benefit will be supplemented beside the financial statements. Contents in reports are classified into non-monetary information and monetary information (Yan-fen, 2002).

Report of human resources could be divided into indicating table and information table of human resources. The indicating table is used to reflect expenditures and revenue of human resources. Expenditure has two parts as capital expenditure and revenue expenditure. Revenue expenditure has impact in one accounting period (such as wages and welfare expenses paid to employees), capital expenditure has impact in more than one accounting period (such as cultivation and training for being employees, living welfare and facilities). The human resources information table mainly reflects non-monetary information (Meng-ya, 2005).

In the regulations of Chinese, the No. 30 China Accounting Standards for Business Enterprise - Financial Statements Report and the No. 31 China Accounting Standards for Business Enterprises - Cash Flow Statement, the item of human resources cost hasn't been established specially, there is only one regulation on the disclosure of payable employees' compensation related with human resources cost in the supplemented information, which shall be disclosed by enterprises, and this is a requirement for information disclosure of enterprise liabilities.

In the above two opinions, item if "human assets" in the balance sheet is the long-term human assets actually; "human resources expenses" in the profit and loss statement or profit statement is regarded as long-term human resources amortization by the first opinion, and human assets amortization and non-capitalized human resources expenses by the second opinion, which contains a larger scope of expenses than the first opinion.

The author thinks the report of human resources cost is a component of human resources report as well as a part of financial statement. The expenditures of human resources cost shall be reflected in the three important statements: balance sheet, profit statement and cash flow statement. Contents need to be included are cash flow of unconsumed 
human resources cost, consumed human resources cost and expenditures of human resources cost. The "long-term human assets", which is assed in intangible assets item in balance sheet, shall reflect long-term initial assets value of human resources, amortization amount and net value. The short-term unconsumed human resources cost (direct labor cost of products, labor cost of manufacturing expenses and unamortized cost of short-term human assets) could be listed in items of inventories and expenses to be apportioned within one year in balance sheet. There are two choices to display consumed human resources cost in profit statement:

(1) Listing direct labor cost of finished products, labor cost in manufacturing expenses, selling of management expenses, wages of managers, amortization amount of human resources and other human resources cost (compensatory spending of dismission) in management expenses;

(2) Only list the human resources expense in management expenses. In the first method, expensed human resources cost information could be obtained from profit statement directly without adjustment. The second method does not make big amendment to existent profit statement. But due to the deficient display of all expensed human resources cost, the human resources expenses information is incomplete. The better way to reflect unconsumed human resources cost (unconsumed human resources cost of long-term human assets and short-term assets, such as products human resources cost and human resources cost to be amortized) and consumed (expensed) human resources cost concentrated is to establish "Statement of Human Resources Costs". The special established human resources cost statement could be the comprehensive attached table of financial statements.

\subsection{Human Resource Accounting and International Financial Reporting Standards}

In recent years General Accepted Accounting Principles (GAAP) has been moving toward adoption of more complex measurement methods in financial reporting compared with the traditional historical cost approach to asset measurement, including of focus on the measurement of the time value of money and present value calculations. Meeting, Luecke and Garceau (2001) indicate that in many cases an expected cash flow approach is a better measurement tool than traditional methods, and that CPAs should use it to report asset and liability values in the absence of specific contractual cash flows. Certain current assets are now reported at their fair market values at each balance sheet date, and many items on the balance sheet that are non current are measured at the present value of the estimated future cash flows.

As accountants have become more accustomed to complex measurement approaches, some similar to the approaches taken in developing human resource accounting value measures, it seems reasonable that nontraditional human resource accounting measures may become more accepted in future financial reports. In addition there has been increased interest in accounting for intangible assets in financial reporting by both the Financial Accounting Standards Board and the Securities and Exchange Commission. As noted in Flamholtz, Bullen and Hoa (2002), since human resources are a primary component of intangible Assets, the state is being set for a renewed interest in human resource accounting from a financial accounting perspective.

Since 2001, the International Accounting Standards Board (IASB) has been developing and promulgating the International Financial Reporting Standard (IASB, 2009). Prior to 2001, the International Accounting Standards committee (IASC) issued International Accounting Standards (IAS), which were adopted initially by the IASB when it replaced the IASC. While the IFRS do not currently have standards requiring human resource accounting, it could be argued that they are moving closer to providing more flexible approaches to accounting measurements and reporting. For example, the International Accounting Standards IAS 38 Intangible Assets and IFRS 3 on Business Combinations allow for the recognition of the intangible asset goodwill, which indicates a Journal of International Business and Cultural Studies Human Resource Accounting, Page 4 willingness to allow for valuation of assets that are not traditional tangible assets, such as human resources. The valuation of goodwill often involves complex assessments of fair values as well as periodic reassessments to determine whether the fair values have become impaired. These more difficult and challenging measurements of goodwill and other fair values are similar to some of the challenges documented in the past related to the measurement of human resources, particularly when using the value approach to human resource accounting. Thus, the movement toward fair value accounting seen in recent years both for U.S. GAAP as well as for International Standards indicates a more sophisticated approach to the measurement of assets, tangible as well as intangible. This might suggest a willingness to recognize the need for, and consider the measurement and use of HRA in future external financial reporting.

\subsection{Human Resource Accounting in Management Reporting and Decision-Making}

In addition to external financial reporting, human resource accounting may be useful as a managerial tool to aid in making managerial decisions that will benefit the long-run strategic goals and profitability of the company. As opposed to external financial reporting, managerial reporting does not require adherence to a strict set GAAP in specific financial 
statements in acceptable format reported to the public (Bullen, 2007). However even if human assets are not reported on the face of external financial statements, human resource accounting can play a crucial role in internal managerial decision-making, and human resource accounting measures can be used to show that investments in a company's human resources may result in long-term profit for the company (Bullen, 2007).

When mangers go through the process of human resource accounting measurement treating human resources as capital assets, they are more likely to make decisions that treat the company's employees as long-term investments of the company. Flamholtz (1979) describes the human resource accounting paradigm in terms of the "Psycho-Technical Systems" (PTS) approach to organizational measurement. According to the PTS approach, the two functions of measurement are:

1) Process functions in the process of measurement, and

2) Numerical information from the numbers themselves.

Whereas one role of human resource accounting is to provide numerical measures, an even more important role is the measurement process itself. The human resource accounting measurement process as a dual function attempts to organization's short and long-term productivity and growth. When managers go through the process of measuring human resources, they are more likely to focus on the human side of the organization and are likely to consider human resources as valuable organizational resources who should be managed as such (Bullen, 2007).

For example in a potential layoff decision, with use of human resource accounting measures in addition to only traditional accounting measures, management is better likely to see the hidden costs to the company's human resources and the long-term implications to the human assets. This is because human resource accounting, views human resources as assets or investments which must be maintained for long-run productivity (Bullen, 2007). Layoffs may affect future long-term profits from lost productivity, costs of rehiring and retraining when business returns, and costs of lower morale of existing workforce. If management quantified the actual costs of layoffs, management might be less inclined to use layoffs as a way to cut costs and boost short-term profit at the expense of long run productivity and profits (Bullen, 2007).

Flamholtz, Bullen and Hua (2003) utilized the human resource accounting measure of expected realization value, and found that employees' participation in a management development program increased the value of the individuals to the firm. In addition the authors noted that the human resource accounting measures provided upper level management with an alternative accounting system to measure the cost and of people to an organization. Thus human resource accounting represented either a paradigm or way of viewing human resource decision, and the set of measures for quantifying the effects of human resource management strategies upon the cost and value of people as organizational resources.

Davidove and Schroeder (1992) indicate that too many business leaders have no generally accepted definition or accounting procedure for tracking training investments, and not that a lower training investment is not automatically better for an overall return on investment. The authors suggest that although many business leaders still view training as an overhead expense, with thorough ROI evaluations training departments can convince business to view them as partners in creating the assets crucial to organizational success.

Other authors have expressed similar views suggesting the benefits of human resource accounting measurements and the process of measuring human resources. For example Johanson and Mabon (1998) indicate that expressing human resource interventions in financial terms and/or cost benefit terms is more effective than using soft accounting information such as data on job satisfaction. Because the classical function of accounting is the determination of the value of the economic activity, performing analysis with hard numbers such as cost-benefit analyses helps us determine how resources should be used by human resources for various interventions. Toulson and Dewe (2004) conducted a survey study utilizing component analysis and found two reasons why measuring human resources is important. The first is that measurement reflects the strategic and competitive importance of human resources, and the second suggests that in earn credibility, human resources must be expressed in financial terms. McKenzie and Milling (2001) suggest that, if properly implemented, the human capital planning and budgeting process will become a key driver of strategy in that strategic human capital planning and budgeting ensures that the best resources are mobilized for each internal process. They indicate that too often organizations focus $100 \%$ on meeting the financial budget first without consideration of the effect the cost slashing will have on strategy, and note that the financial numbers are a lagging indicator of where a firm has been and should not be substituted for leasing indicators of where the firm is going. Rather management should focus clearly on causal, leading indicators that drive successful financial measures, and that it is through skills-based budgeting that the fallacy of financial focus can be avoided. 
Moore (2007) suggests that the value of human capital should be more fully considered when making decisions about the acquisition and disposal of people and notes that the accounting practices currently employed by companies can have an undue influence in driving the strategic decisions of these companies. Moore notes that there are parallels between the process of acquiring an employee (a human capital asset) and that of acquiring a fixed capital asset. However while most companies acknowledge the contributions of its employees, they do not think of the acquisition or disposal of human capital assets in the same way or with the same thoughtful planning or strategic thinking as they do fixed capital assets.

\subsection{International Developments in Human Resource Accounting}

Interest in HRA related reporting has grown in a number of countries across continents. In discussing "HR metrics", Hansen (2007) notes that two thirds of the 250 largest companies in the world now issue sustainability reports along with their financial reports in order to capture the full value of the organization. Global standards for sustainability reporting require the disclosure of workforce data that reflect the potential for future performance and profitability. Sustainability reporting has been formalized under guidelines by the Global Reporting Initiative, an international network of business, labor investors and accountants. Schwartz and Murphy (2008) also comment on human capital metrics, suggesting that a class on the subject would benefit all undergraduate management majors. They suggest that primary among those benefits is a change in mind set toward using data and metrics to design and evaluate management policy rather than relying on experience, fad or hype and suggest that students familiar with human resource metrics should be better equipped to prove and enhance the contributions of human resources to their organizations.

Some research has included aspects of human resource accounting in studies examining and comparing reporting practices of a number of countries. A study by Subbarao and Zehgal (1997) gave a macro-level perspective to human resource accounting disclosure in financial statements by analyzing the differences across countries in the disclosure of human resources information disclosure in annual reports across six countries. The authors found differences in disclosures of HR information across countries and provided accounting and financial professional insights on the HR information areas they need to focus on in their country. In another study, Boedker, Mouritsen and Guthrie (2008) examined contemporary trends from Europe, Australia, and the United States, in "Enhanced Business Reporting" (EBR), which includes aspects of human resource accounting. The authors found a vast diversity in international EBR practice, including measurement and reporting models, and suggested the need for further research about the barriers to and consequences of harmonization.

\section{Research Methodology}

An analytical ex-post facto approach is used. Secondary information has been obtained from specialized studies and scientific sources, while primary information was generated through a questionnaire.

The studied population consists of 10 companies listed in the Nigerian Stock Exchange (NSE). Copies of the questionnaires were distributed to all companies.

On the basis of previous studies, the questionnaire was designed in two parts: Section "A" contained items seeking information on the demographic characteristics of respondents such as sex, age, and level of education of respondents. Section "B" contained items seeking further information to measure the major variables of the study (acquisition cost, development cost, and corporate productivity).

In section "B", a five point Likert scale measurement was used to show the opinions of the study sample members on the questionnaire items. In order to find the arithmetic means of the opinions of sample members, weights were designated in agreement with the significance of each paragraph of the questionnaire, where the weight (5) was designated to the case of "strongly agree," (4) to the case of "agree," (3) to the neutral case (average), (2) to "disagree," and (1) to "strongly disagree." The items here were positively and negatively worded.

\subsection{Validation and Reliability of the Instrument}

The content and face validity of the instrument (HRCPAS) of the study was established by the researcher. The instrument was presented to two experts in quantitative analysis in Faculty of Management Sciences, University of Calabar, to ascertain whether or not the items on the instrument were related to the hypotheses which were required to test. The feedback from the experts showed that the items on the instrument were adequate in generating data required to test the hypotheses. Finally, they were presented to the project supervisor who vetted the instruments and removed irrelevant items, introduced new ones and approved them for administration.

To establish the reliability of the instrument the researcher carried out a trial testing using 60 respondents randomly selected from two companies, but which was not part of the sampled clusters of the study. This was done by randomly 
selecting 30 respondents from each company. The instrument (questionnaire) was administered to these respondents to fill and the questionnaire was retrieved and prepared by scoring/coding; and the codes of the items split into two halves of even and odd number items. The two halves were then subjected to reliability analysis of the split-half method, using Pearson Product Moment Correlation analytical procedure.

$<$ Table 1 about here $>$

The analysis produced correlation coefficients $\left(\mathrm{r}_{\mathbf{x y}}\right)$ ranging from 0.58 to 0.71 (See Appendix). These coefficients were then converted to reliability estimates $\left(\mathrm{r}_{\mathrm{tt}}\right)$ using the spearman Brown prophecy formula as ascertain by Denga and Ali (1994).

\subsection{Model Specification}

The economic model used in the study (which was in line with what is mostly found in the literature) is a multiple regression model given as:

$$
\mathrm{CP}=\mathrm{f}(\mathrm{HRAC}, \mathrm{HRDC})
$$

The statistical model becomes:

$$
\mathrm{CP}=\mathrm{B}_{0}+\mathrm{B}_{1} \mathrm{HRAC}+\mathrm{B}_{2} \mathrm{HRDC}+\mathrm{u}
$$

Where;

Expected

$\mathrm{CP}=$ Corporate Productivity

HRAC $=$ Human Resources Acquisition Cost

$\underline{\text { Sign }}$

HRDC $=$ Human Resources Development Cost

$+$

$\mathrm{B}_{0}=$ Unknown constant to be estimated

$\mathrm{B}_{1} \& \mathrm{~B}_{2}=$ Unknown coefficients to be estimated

$\mathrm{u}=$ Stochastic error term

$\mathrm{B}_{0}, \mathrm{~B}_{1}, \mathrm{~B}_{2} \geq 0$

\section{Data Analysis}

$<$ Table 2 about here $>$

Table 2 shows the summary of the regression results of the influence of human resources capitalized cost (HRAC and HRDC) on corporate productivity. From the result, it could be found that all the independent variables are significant in the model.

The explanatory power of the model as informed by the adjusted R-square is 0.841 or $84.1 \%$, and is statistically significant given the high value of the F-statistic (i.e. 45.765). The Durbin Watson (DW) value is 2.004, which fall within the region of no autocorrelation.

The model demonstrates a good fit given that about $84.1 \%$ of the variations in the dependent variable (CP) is jointly explained by changes in the observed behaviour of HRAC and HRDC. The relatively high adjusted R-square of 0.805 $(80.5 \%)$, shows that the model fits the data well. About $15.9 \%$ variations in CP can be explained by other unknown variables not captured in the present model. The high significant $F$-statistic value $\left(\mathrm{df}_{1}=2\right.$, and $\left.\mathrm{df}_{2}=997\right)$ of $45.765(\mathrm{P} .000)$ confirms that the high adjusted R-square did not arise by chance [N/B: F0.01 $\left(\mathrm{df}_{1}=2\right.$, and $\left.\left.\mathrm{df}_{2}=997\right)=4.61\right]$. Therefore, the model is robust.

The test of significance shows that all the variables are significant when compared with the table value of 2.58 (See Table 2) at 1\% level, and then the two variables are significant at $1 \%$ level. Specifically, a $1 \%$ increase or decrease in HRAC and HRDC would lead to an increase or decrease in corporate productivity with a margin of 0.70 and 0.23 respectively.

The test for autocorrelation, the calculated DW is 2.004. From the table DW reading, one makes use of the following information: $\mathrm{K}=3$ variables, $\mathrm{n}=1000$ and at $5 \%$ level: $\mathrm{du}=1.771,4-\mathrm{du}=2.229, \mathrm{dI}=1.335$ and $4-\mathrm{dI}=2.665$. By inspection, the DW value of 2.004 falls within the du and 4du region (i.e. 1.771 and 2.229 in this case), therefore our calculated DW falls within the region of no autocorrelation. 


\subsection{Discussion of Findings}

Our analysis and empirical results has shed some insight on human resources cost and its influence on corporate productivity.

The result of this study has provided relatively strong support for the existence of a positive relationship between human resources cost and the performance of Nigerian corporations. At a general level, this result is largely consistent with results obtained by Becker and Gerhart, (1996); Guest, (1997); Becker and Huselid, (1998) in their studies on HRM and firm performance conducted in other geographical settings. They separately found out that human resources cost have an economically and statistically significant impact on turnover and corporate productivity.

The findings of this study also revealed that capitalized human resources cost is an important determinant of company performance. This result is in line with findings arrived at by Delaney and Huselid (1996) who in their study classified capitalized human resources cost into acquisition and development costs and that human resource management practices are related to the development of the human resources of the firm. Also in line with the findings of this study is the finding arrived at by Koch and McGrath (1996) who found out that company investing in both acquisition and development of human resources are likely to have a positive impact on the extent to which the firm actually succeeds in developing the skills/knowledge of its employees.

The study also revealed that development (training) cost is highly and significantly related to the performance of corporate entities in Nigeria. This result is highly supported by MacDuffie (1995) who found out that positive relationship has been established between employee training and organizational performance.

\section{Conclusion and Recommendations}

Just as the field of human resource accounting has grown globally, significant interest in HRA has expanded and crossed over in to fields others than accounting including economics, organizational management and organizational culture and inspired related research. This study has explored how human resource accounting measures incorporated corporate performance measurement system can help an organization define and orchestrate its strategy for success. The human resources cost approach to corporate performance measurement which has gained substantial attention and use in recent years provides further opportunities for utilization of human resource accounting measures. A growing number of studies have attempted to show the link between human resources and performance. We believe that though the case is not watertight, due to a number of methodological reasons, the weight of evidence is beginning to look compelling.

In the context of this study's objectives and findings, it is the opinion of the researcher to make the following recommendations:

(i) Companies should use career management programs to assist their employees in career planning. When the company provides this service, one important aim is to identify sequences of job assignments that help employees gain the skills and knowledge viewed as important in the company. A well-functioning company career planning system may also encourage employees to take more responsibility for their own development, including the development of skills viewed as significant in the company. It should be noted that a career planning system not only helps ensure that employees have the skills they need to advance in the company, but also may help ensure that employees possess the mix of skills that the firm believes is important for its future success. In other words, the provision of career planning assistance may have a positive effect on the level and type of skills and knowledge in the company.

(ii) Employment security should be seen as an important part of high performance HRM practices. Companies that provide their employees with job security signal a long-standing commitment to their workforce, whom in turn is more motivated to develop special skills and competencies that are valued by their company. Employees who perceive that their jobs are secure are also more likely to suggest productivity improvements and to take a more comprehensive and long-term view of their jobs and the company's performance.

(iii) Organizations would also be able to realize a return on investment in certain programs which would increase the efficiency and effectiveness of their human resources, and this could be further utilized as a benchmark measurement for inter-company comparison in the same industry.

\subsection{Suggestions for Further Research}

In appraising this study's findings, the interested person is advised to keep in view the following observations and limitations.

First, the overall objective of the study was to determine the extent to which human resources cost influences corporate productivity. Because non-availability of required data limited the extent of the analysis performed, there is need for 
future researchers to follow our lead and collect separate data for different employee groups despite the additional challenges this causes.

Second, research in other geographical settings is also clearly warranted to see how generalizeable/divergent results are.

Further, on the methodological constraint, this study basically made used of the ordinary least square (OLS) method. With its theoretical weaknesses, it is suggested that other sophisticated data treatment techniques such as co-integration, path analysis and error correction modeling (ECM) be use. The ECM will make the regression analysis free from any spuriously generated results.

Finally, researchers should address in future the following research questions:

1. How does one educate the users of financial statements about the usefulness of measuring human resource value and create more awareness?

2. Who should drive the measurement of human resource value?

3. Which model for the recording of human resource value is most suited to the Nigerian organizations?

\section{References}

American Accounting Association (1974). Statement of basic accounting theory. The Accounting Review Supplement. 49: 85-93.

Bailey, T. (1993). Discretionary effort and the organization of work: Employee participation and work reform. New York: McGraw Hill.

Becker, B. E. \& Barry, G. (1996). The impact of human resources management on organizational performance: progress and prospects; Academy of Management Journal; 39 (4) 779-801. http://dx.doi.org/10.2307/256712

Becker, B. E. \& Huselid, M. A. (1992). Direct estimates of SDy and the implications for utility analysis. Journal of Applied Psychology, 77:227-233. http://dx.doi.org/10.1037/0021-9010.77.3.227

Becker, G. S. (1964). Human capital. New York: McGraw Hill

Boedker, C., Mouristan, J. \& Guthrie, J. (2008). Enhanced business reporting: International trends and possible policy directions; Journal of Human Resource Casting \& Accounting, 12 (1), 14-15. http://dx.doi.org/10.1108/14013380810872734

Boudreau, J. W. \& Berger, C. J. (1985). Decision-theoretic utility analysis applied to employee separations and acquisitions. Journal of Applied Psychology. 70:581-612. http://dx.doi.org/10.1037/0021-9010.70.3.581

Brummet, R. L. (1970). Accounting for human resource, The Journal of Accountancy, 4: 62-66.

Bullen, M. L. (2007). Human resource accounting: A useful tool for measurement and management in organizations. Leadership and Organizational Management Journal, 5, 85-103.

Cascio, W. F. (1991). Costing human resources: The financial impact of behaviour in organizations. Boston: PWS-Kent.

Cascio, W. F. (1998). The future world of work: Implications for human resources costing and accounting. Journal of Human Resource Casting \& Accounting, 3(2) 9-19. http://dx.doi.org/10.1108/eb029045

Davidove, E. A. \& Schroeder, P. A. (1992). Demonstrating return on investmen. [Online] Available: www.traininganddevelopment.

Delaney, J. T. \& Huselid, M. A. (1996). The impact of human resource management on rerceptions of organizational performance. Academy of Management Journal, 39:949-969. http://dx.doi.org/10.2307/256718

Flamholtz, E. G. (1979). Towards a psycho-technical systems paradigm of organizational measurement. Decision Sciences, 4, 71-84. http://dx.doi.org/10.1111/j.1540-5915.1979.tb00008.x

Flamholtz, E. G., Bullen, M. L., \& Hua, W. (2002). Human resource accounting: A historical perspective and future implications. Management Decision, 40 (10), 947-54. http://dx.doi.org/10.1108/00251740210452818

Flamholtz, E. G., Bullen, M. L., \& Hua, W. (2003). Measuring the ROI of management development: An application of the stochastic rewards valuation model. Journal of Human Resource Costing and Accounting, 7 (1-2), 21-40. http://dx.doi.org/10.1108/eb029077

Flamhotz, E. G. and Lacey J. M. (1981). Personnel management, human capital theory, and human resource accounting. Los Angeles: Los Angeles University Press. 
Frederickson, N. (1986). Toward a broader conception of human intelligence. American Psychology. 41: 445-452. http://dx.doi.org/10.1037/0003-066X.41.4.445

Guest, D. E. (1997). Human resource management and performance: A review and research agenda. International Journal of Human Resource Management, 8: 263-276. http://dx.doi.org/10.1080/095851997341630

Hansen, B. (2007). Personnel investments and abnormal return. Journal of Human Resource Costing and Accounting, 2 (2), 9-29. http://dx.doi.org/10.1108/eb029037

International Accounting Standards Board (2009): Employee Benefits. [Online] Available: http://www.iasb.org

Johanson, U. \& Mabon, H. (1998). The personnel economics institute after ten years. Journal of Human Resource Costing and Accounting, 19(2), 86-92

Katz, D. \& Kahn, R. L. (1978). The social psychology of organizations. New York: Wiley.

Koch, M. J. \& McGrath, R. G. (1996). Improving labour productivity: Human resource management policies do matter. Strategic Management 17:335-354. http://dx.doi.org/10.1002/(SICI)1097-0266(199605)17:5<335::AID-SMJ814>3.0.CO;2-R

Kozlowski, S. W. J. \& Salas E. (1994). A multilevel organizational systems approach for the implementation and transfer of training. Retrieved on August $4^{\text {th }}, 2010$ from www.trainingeffectiveness.org.

Likert, R. M. (1960). The human organization: Its management and value, New York: McGraw-Hill.

Luecke, R. M. \& Garceau, E. G. (2001). Human organizational measurement: Key to financial success; Michigan Business Review, 4 (1), 57-63.

MacDuffie, J. P. (1995). Human resource bundles and manufacturing performance: Flexible production systems in the world auto industry. Industrial Relations \& Labour Review, 48:197-221.

McKenzie, J. L. \& Melling, G. L. (2001). Skills-based human capital budgeting: A strategic initiative, not a financial exercise. Cost Management, 15(3) 30-38.

Meng-ya, Y. (2005). On human resources accounting practical application, China; Journal of Dalian Maritime University, 3 (2) 32- 40.

Moore, R. (2007). Measuring how human capital appreciates in value over time plant engineering. Retrieved on June $24^{\text {th }}$ from www.humancapitalappreciates.

Porter, M. E. (1985). Competitive advantage: Creating and sustaining superior performance. New York: Free Press.

Prasad, M, \& Kumar V.S. (2006). Valuing human resource-an empirical approach: A case study of port of Visakhapatnam. Management and Accounting Research, 10 (2) 6-17.

Russell, C. J., Colella, A., \& Bobko, P. (1993). Expanding the context of utility: The strategic impact of personnel selection. Personnel Psychology. 46:781-801. http://dx.doi.org/10.1111/j.1744-6570.1993.tb01569.x

Schuler, R. S. \& Macmillan, I. C. (1984). Gaining competitive advantage through human resource management practices, Human Resource Management, 23 (3) 241-256. http://dx.doi.org/10.1002/hrm.3930230304

Schwarz, J. L. \& Murphy, R. E. (2008). Human capital metrics: An approach to teaching using data and metrics to design and evaluate management practices. Journal of Management Education 32 (2), 164. http://dx.doi.org/10.1177/1052562907307638

Snell, S. A. (1992). Control theory in strategic human resource management: The mediating effect of administrative information; Academic Management Review. 35: 292-327. http://dx.doi.org/10.2307/256375

Subbarao, A. V. \& Zehgal, D. (1997). Human resources information and disclosure in annual reports: An international comparison. Journal of Human Resource Costing and Accounting, 2 (2), 53-73. http://dx.doi.org/10.1108/eb029039

Toulson, P. K. \& Dewe, P. (2004). Human resource accounting as a measurement tool. Human Resource Management Journal. 14 (2), 75-90. http://dx.doi.org/10.1111/j.1748-8583.2004.tb00120.x

Tsang, M. C, Rumberger, R. W, \& Levin, H. M. (1991). The impact of surplus schooling on worker productivity. Industrial Relations, 30: 209-28. http://dx.doi.org/10.1111/j.1468-232X.1991.tb00786.x

Von-Bertalanffy, L. (1950). The theory of open systems in Physics and Biology. 111:23-29. http://dx.doi.org/10.1126/science.111.2872.23 
Wan-xiang, L. (2001). On cost. Beijing: China Financial and Economic Publishing House.

Williamson, O. E. (1979). Transaction cost economics: The governance of contractual relations. Journal of Law Economics. 22 (2):233-261. http://dx.doi.org/10.1086/466942

Williamson, O. E. (1981). The modern corporation: Origins, evolution, attributes. Journal of Economics Literature. 19: 1537-1568.

Wright, P. M, \& McMahanm, G. C. (1992). Human resources and sustained competitive advantages: A resource-based perspective, International Journal of Human Resources Management, 5 (2) 299-324.

Wright, G. Mckenzie, R. C, \& Muldrow, T. W. (1994). Human resources and the resource-based view of the firm. Journal of Management, 27: 701-721. http://dx.doi.org/10.1177/014920630102700607

Wright, P. M. \& Snell, S. A. (1991). Human resources management. Retrieved on 23 ${ }^{\text {rd }}$, June, 2010 from www.development/acq.

Yan-fen, L. (2002). Cost accounting. Shanghai: Shanghai University of Finance and Economics Press.

Table 1. The Split Estimate or Reliability of Measure of Research Variables. $(\mathrm{N}=60)$

\begin{tabular}{|c|c|c|c|c|c|c|}
\hline Variables & No. of Items & Testing & X & SD & $\mathrm{R}_{\mathrm{xy}}$ & $\mathrm{R}_{\mathrm{tt}}$ \\
\hline Corporate Productivity (CP) & 3 & $1^{\text {st }}$ Half & 6.15 & 1.42 & 0.58 & 0.70 \\
\hline & 3 & $2^{\text {nd }}$ Half & 6.21 & 1.30 & & \\
\hline Acquisition Cost (HRAC) & 3 & $1^{\text {st }}$ Half & 5.81 & 2.18 & 0.64 & 0.78 \\
\hline & 3 & $2^{\text {nd }}$ Half & 6.31 & 1.58 & & \\
\hline Development Cost (HRDC) & 3 & $1^{\text {st }}$ Half & 5.82 & 1.68 & 0.71 & 0.80 \\
\hline & 3 & $2^{\text {nd }}$ Half & 6.85 & 1.85 & & \\
\hline
\end{tabular}

Source: Researcher's estimation, 2010

Table 2. Regression results of the relationship between capitalized human resources cost and corporate productivity

\begin{tabular}{|c|c|c|c|c|}
\hline Variable & Estimated Coefficients & Standard Error & T-Statistic & P-Value \\
\hline $\mathrm{C}$ & 19.580 & .604 & 32.416 & .000 \\
\hline HRAC & .697 & .008 & 2.832 & .005 \\
\hline HRDC & .227 & .025 & 9.035 & .000 \\
\hline \multicolumn{5}{|c|}{$\mathrm{R}^{2}=0.810$} \\
\hline \multicolumn{5}{|c|}{$\mathrm{R}^{2}(\operatorname{adj})=0.805}$. \\
\hline \multicolumn{5}{|c|}{ F-Statistic $\left(\mathrm{df}_{1}=2 \& \mathrm{df}_{2}=997\right)=45.765(\mathrm{P} .000)$} \\
\hline \multicolumn{5}{|c|}{$\mathrm{DW}=2.004$} \\
\hline \multicolumn{5}{|c|}{$\mathrm{SER}=27.532$} \\
\hline \multicolumn{5}{|c|}{$\mathrm{n}=1000$} \\
\hline \multicolumn{5}{|c|}{ Dependent variable: $\mathrm{CP}$} \\
\hline
\end{tabular}

Source: Researcher's estimation, 2010 